\title{
Further field testing of the more heat-stable measles vaccines in Cameroon
}

\author{
DAVID L HEYMANN, ETHLEEN L SMITH, JAMES H NAKANO, JOHNSON G JATO, \\ GLADYS E MARTIN, GEORGES KESSENG MABEN
}

\begin{abstract}
Two of the more heat-stable measles vaccines were field tested in Cameroon. Both maintained the minimum required infectivity titre and the ability to induce seroconversion after storage unreconstituted at $37^{\circ} \mathrm{C}$ for 14 days. One of the vaccines, studied after reconstitution, maintained its ability to induce seroconversion after reconstitution and storage at $25^{\circ} \mathrm{C}$ for 48 hours and at $37^{\circ} \mathrm{C}$ for at least four hours.

The increased heat stability of the studied vaccines will not eliminate the need for a well-monitored system of vaccine conservation and distribution but will ease the rigid cold-storage requirements of conventional measles vaccines.
\end{abstract}

\section{Introduction}

Measles is an important cause of death among children in the developing world, and case fatality rates may be as high as $7 \% .^{1}$ Efforts to control the disease are often hindered by administra-

Centres for Disease Control, Atlanta, Georgia 30333 USA

DAVID L HEYMANN, MD, medical epidemiologist (formerly assigned to Organisation pour la Lutte Contres les Endemies en Afrique Centrale (OCEAC), Yaoundé, Cameroon)

ETHLEEN L SMITH, MT (ASCP), laboratory technician (formerly assigned to Disease Surveillance Laboratory (OCEAC), Yaoundé, Cameroon)

JAMES H NAKANO, PHD, virologist, viral exanthems branch, virology division, Centre for Infectious Disease

University Centre for Health Sciences (CUSS), Yaoundé, United Republic of Cameroon

JOHNSON G JATO, PHD, co-ordinator, pharmaceutical sciences

GLADYS E MARTIN, DCH, MPH, project co-ordinator UCHS, UY

Ministry of Public Health, Yaoundé, United Republic of Cameroon GEORGES KESSENG MABEN, DM, assistant director, Department of Public Health tion of vaccines inadvertently inactivated by heat because of logistic problems such as unreliable or non-existent coldstorage equipment or inadequate maintenance and monitoring systems for conserving vaccine. ${ }^{2}$

The development of the more heat-stable measles vaccines during the past few years has helped to overcome some of the problems associated with cold storage. At $2^{\circ}-8^{\circ} \mathrm{C}$ these improved vaccines maintain the minimum required infectivity titre $\left(10^{3}\right.$ $\mathrm{TCID}_{50} /$ dose) for more than two years. ${ }^{34}$ Their stability is even more pronounced at higher temperatures. Rimevax, a more heat-stable measles vaccine studied by us in 1979, showed negligible loss in virus titre during seven days of storage at $25^{\circ} \mathrm{C}$ and induced seroconversion in $122(92 \%)$ of 132 children vaccinated. ${ }^{5}$

During the past year a second generation of Rimevax, stable at higher temperatures, and a second more heat-stable measles vaccine, Attenuvax, have become available. Both vaccines have been shown by their manufacturers to maintain the minimum required infectivity titre after 14 days of storage at $37^{\circ} \mathrm{C.} .^{3}$ In addition, reconstituted Attenuvax reportedly maintains this titre after 48 hours at $24^{\circ} \mathrm{C}$ and after seven hours at $37^{\circ} \mathrm{C}$. We assessed these two improved vaccines under controlled field conditions in sub-Saharan Africa by determining seroconversion rates after storage at $37^{\circ} \mathrm{C}$ for periods up to 14 days. We also determined seroconversion rates to reconstituted Attenuvax stored at $25^{\circ} \mathrm{C}$ for periods up to 48 hours and at $37^{\circ} \mathrm{C}$ for periods up to six hours. Finally, based on our results we formulated guidelines for transport and use of these more heat-stable vaccines in the developing world.

\section{Methods}

Study population-Children 9-24 months of age living in rural, south-central Cameroon were selected for study from children attending routine immunisation clinics. Children with a history of measles or measles vaccination were excluded. Before enrolment the study was explained to the accompanying parent, whose consent was obtained.

Seroconversion after storage at $37^{\circ} \mathrm{C}$-Ten dose phials of Rimevax and Attenuvax from routine manufacturers' stocks and within three 
months of manufacture were transferred from storage at $-20^{\circ} \mathrm{C}$ to a dark container and maintained at $37^{\circ} \mathrm{C}$ in a standard bacteriology incubator. Temperature was monitored with a recording thermometer. After 24 hours, and at varying time intervals to a maximum of 312 hours, the lyophilised vaccine was reconstituted with diluent at room temperature (about $25^{\circ} \mathrm{C}$ ) and immediately administered to the study children. At the end of the 312 -hour storage period at $37^{\circ} \mathrm{C}$ two phials of each vaccine were returned to storage at $-20^{\circ} \mathrm{C}$ for later titration. Vaccine virus infectivity titration was performed by standard procedures at the Centres for Disease Control. Capillary blood specimens were obtained by finger puncture before and 30 days after immunisation. Blood was collected on absorbent filter-paper discs as described by Mathews, ${ }^{6}$ dried for 24 hours, and stored sealed with a desiccant at $-20^{\circ} \mathrm{C}$ until analysis. Determinations of measles haemagglutination inhibition antibody were performed by techniques of Hierholzer and Suggs ${ }^{7}$ and Norrby. ${ }^{8}$ Seroconversion was defined as a rise in titre of measles haemagglutination inhibition antibody from seronegative $(<1 / 10)$ to $\geqslant 1 / 20$. Children with a haemagglutination inhibition antibody titre of $\geqslant 1 / 10$ in the prevaccination blood specimen were considered immune at the time of vaccination and not included in the analysis.

Seroconversion after storage of reconstituted vaccine at $25^{\circ} \mathrm{C}$ and $37^{\circ} \mathrm{C}$ -Ten dose phials of Attenuvax from routine manufacturers' stocks and within three months of manufacture were removed from storage at $-20^{\circ} \mathrm{C}$ and reconstituted with diluent at room temperature (about $25^{\circ} \mathrm{C}$ ) using sterile needle and syringe. The reconstituted vaccine was stored in a dark container at $25^{\circ} \mathrm{C}$ for up to 48 hours and at $37^{\circ} \mathrm{C}$ for up to six hours. After storage intervals of 24 and 48 hours at $25^{\circ} \mathrm{C}$ and of four and six hours at $37^{\circ} \mathrm{C}$ the reconstituted vaccine was removed from storage and immediately administered to study children. Blood specimens were obtained before and 30 days after vaccination and analysed as previously described.

Revaccination of study population - The study was performed during a period when the incidence of measles transmission was low. At the time of collection of the second capillary blood specimen all study children were revaccinated with vaccine that had been kept frozen at $-20^{\circ} \mathrm{C}$ until reconstitution and use. Parents were questioned at the time of collection of the second blood specimen to ascertain that study children had not had measles-like disease during the interval since vaccination.

\section{Results}

Of 522 children enrolled in the study, 427 remained for analysis after exclusion of those who failed to comply and those with prevaccination measles haemagglutination antibody titres of $\geqslant 1 / 10$. Of 137 seronegative children vaccinated with Rimevax after storage at $37^{\circ} \mathrm{C}$ for up to 14 days, $134(98 \%)$ seroconverted; 191 of $198(96 \%)$ seronegative children vaccinated with Attenuvax stored at $37^{\circ} \mathrm{C}$ for up to 14 days seroconverted (table I). The titre of both Rimevax and

TABLE I-Seroconversion to Rimevax and Attenuvax among children aged 9-24 months, Cameroon 1979, after storage of unreconstituted vaccine at $37^{\circ} \mathrm{C}$

\begin{tabular}{|c|c|c|c|c|}
\hline \multirow[b]{2}{*}{$\begin{array}{l}\text { Duration of } \\
\text { storage at } \\
37^{\circ} \mathrm{C} \\
\text { (hours) }\end{array}$} & \multicolumn{2}{|c|}{ Rimevax } & \multicolumn{2}{|c|}{ Attenuvax } \\
\hline & $\begin{array}{c}\text { No of seronegative } \\
\text { children } \\
\text { vaccinated, with } \\
\text { 30-day follow-up }\end{array}$ & $\begin{array}{l}\text { No }(\%) \text { sero- } \\
\text { converted }\end{array}$ & $\begin{array}{l}\text { No of seronegative } \\
\text { children } \\
\text { vaccinated, with } \\
\text { 30-day follow-up }\end{array}$ & $\begin{array}{l}\text { No }(\%) \text { sero- } \\
\text { converted }\end{array}$ \\
\hline $\begin{array}{c}24-48 \\
49-72 \\
73-96 \\
97-120 \\
121-144 \\
145-168 \\
169-192 \\
289-312\end{array}$ & $\begin{array}{l}24 \\
15 \\
19 \\
16 \\
14 \\
16 \\
16 \\
17\end{array}$ & $\begin{array}{l}23(96) \\
15(100) \\
19(100) \\
16(100) \\
14(100) \\
16(100) \\
15(94) \\
16(94)\end{array}$ & $\begin{array}{l}48 \\
28 \\
23 \\
10 \\
24 \\
13 \\
23 \\
29\end{array}$ & $\begin{array}{l}46(96) \\
28(100) \\
22(96) \\
10(100) \\
24(100) \\
13(100) \\
23(100) \\
25(86)\end{array}$ \\
\hline Total & 137 & $134(98)$ & 198 & $191(96)$ \\
\hline
\end{tabular}

Attenuvax was $>10^{3.5} \mathrm{TCID}_{50} /$ dose after the 312 -hour storage period at $37^{\circ} \mathrm{C}$.

Among seronegative children vaccinated with reconstituted Attenuvax stored for up to 48 hours at $25^{\circ} \mathrm{C}, 19$ out of $20(95 \%)$ seroconverted. Among seronegative children vaccinated with reconstituted Attenuvax stored for four hours at $37^{\circ} \mathrm{C}, 12$ out of 13 $(92 \%)$ seroconverted, while among those vaccinated with recon- stituted Attenuvax stored for six hours at $37 \mathrm{C}, 31$ out of $40(78 \%)$ 品 seroconverted (table II). Though there was a decrease in the seroconversion rate to reconstituted Attenuvax that had been stored at $\mathbb{Q}$ $37^{\circ} \mathrm{C}$ for six hours as compared with that stored at $37^{\circ} \mathrm{C}$ for four $\mathrm{C}$ hours, this decrease was not statistically significant $(p=0 \cdot 19$, Fisher's exact test).

TABLE II-Seroconversion to Attenuvax in children aged 9-24 months, Cameroon 1979-80, after storage of reconstituted vaccine at $25^{\circ} \mathrm{C}$ and $37^{\circ} \mathrm{C}$

\begin{tabular}{cccc}
\hline $\begin{array}{c}\text { Duration of } \\
\text { storage } \\
\text { (hours) }\end{array}$ & $\begin{array}{c}\text { Storage } \\
\text { temperature } \\
\left({ }^{\circ} \mathrm{C}\right)\end{array}$ & $\begin{array}{c}\text { No of seronegative } \\
\text { children vaccinated, } \\
\text { with 30-day follow-up }\end{array}$ & $\begin{array}{c}\text { No (\%) } \\
\text { seroconverted }\end{array}$ \\
\hline 24 & $25^{\circ}$ & 19 & $18(95)$ \\
48 & $25^{\circ}$ & 20 & $19(95)$ \\
4 & $37^{\circ}$ & 13 & $12(92)^{*}$ \\
6 & $37^{\circ}$ & 40 & $31(78)^{*}$ \\
\hline
\end{tabular}

${ }^{*} \mathrm{p}=0 \cdot 19$ (Fisher's exact test)

\section{Discussion}

Unreconstituted Rimevax and Attenuvax maintained both the minimum required infectivity titre and the ability to induce seroconversion after storage at $37^{\circ} \mathrm{C}$ for 14 days. Reconstituted Attenuvax maintained its ability to induce seroconversion after storage at $25^{\circ} \mathrm{C}$ for 48 hours and at $37^{\circ} \mathrm{C}$ for at least four hours.

The increased stability of these vaccines will overcome many of the cold-storage and logistic problems in transporting and using measles vaccine in the developing world. Stability of unreconstituted measles vaccine at $2^{\circ}-8^{\circ} \mathrm{C}$ permits storage for up to two years in the refrigerator. Stability at higher temperatures permits transport of measles vaccine at ambient temperature provided that the vaccine is continuously monitored so that the temperature and time limits of stability are not exceeded. Though transport at ambient temperature is not recommended routinely, it may inadvertently occur when the chain of coldstorage facilities fails during transport of vaccines, and it may be necessary to ship measles vaccine from regional storage depots to remote areas without refrigeration.

Stability of the more heat-stable measles vaccines after reconstitution permits use of reconstituted measles vaccine for at least four hours at a temperature of $37^{\circ} \mathrm{C}$ and for 48 hours at $25^{\circ} \mathrm{C}$. As with all biological preparations, reconstituted heatstable measles vaccines must be reconstituted using standard sterile technique. Because of the risk of bacterial contamination during reconstitution or aspiration and resultant bacterial proliferation, the reconstituted vaccine should be stored away from direct light at a temperature between $2^{\circ} \mathrm{C}$ and $8^{\circ} \mathrm{C}$ when not in use and should be given within eight hours of reconstitution.

The increased stability of these vaccines does not eliminate the need for a well-monitored system of vaccine conservation and distribution. Their increased stability does ease the rigid cold-storage requirements of conventional measles vaccines, thereby decreasing wastage due to temporary failure of cold storage, facilitating transport to remote areas, and prolonging the period of use after reconstitution at immunisation sites. The World Health Organisation's minimum criteria of stability for the more heat-stable measles vaccines require that at the time of manufacture the vaccine should retain a virus infectivity titre of $10^{3} \mathrm{TCID}_{50} /$ dose after seven days of storage at $37^{\circ} \mathrm{C}$. $^{9}$ Stability of the two vaccines studied here was greater than this and varied with the initial virus infectivity titre of the lot. Hence to establish temperature and time limits for use of a measles vaccine designated as more heat stable, manufacturer's stability data and date of manufacture of each lot must be known.

Using the trade names Rimevax and Attenuvax is for identification only and does not imply endorsement by the Public Health Service of the US Department of Health and Human Services.

Requests for reprints should be addressed to the International 
Health Programme Office, Centres for Disease Control, Atlanta, Georgia 30333 USA.

\section{References}

${ }^{1}$ Martin WJ, Morley DC, Woodland M. Interval between births in a Nigerian village. $\mathcal{F}$ Trop Pediatr 1964;10:82.

2 McBean AM, Foster SO, Herrmann KL, et al. Evaluation of a mass measles immunization campaign in Yaoundé, Cameroon. Trans $R$ Soc Trop Med Hyg 1976;70:206-12.

${ }^{3}$ Peetermans J. Vaccin Rougeoleux Vivant Attenue (Souche Schwarz) pour injection. Recherches et Industrie Therapeutiques, SA Welwyn Garden City: Smith, Kline and French, 1979. (Product data.)

${ }^{4}$ McAleer WJ, Markus HZ, McLeen AA, Buynak EB, Hilleman MR. The stability on storage at various temperatures of line measles, mumps and rubella virus vaccines in a new stabiliser. 7 Biol Stand 1980;8:281-7.

${ }^{5}$ Heymann DL, Nakano JH, Durand B, et al. Field trials of a heat-stable measles vaccine in Cameroon. $\mathrm{Br}$ Med $\mathcal{F}$ 1979;ii:99-100.

${ }^{6}$ Mathews HM. Persistence of malaria antibody in Tobago, West Indies, following eradication as measured by the indirect hemagglutination test. Am 7 Trop Med Hyg 1970;19:581.

${ }^{7}$ Hierholzer JC, Suggs MT. Standardization of viral hemagglutination and hemagglutination tests of erythrocyte suspensions. Applied Microbiology $1969 ; 18: 816$.

${ }^{8}$ Norrby E. Hemagglutination by measles virus. Proc Soc Exp Biol Med $1962 ; 11: 814$.

${ }^{9}$ World Health Organisation. Stability of freeze-dried measles vaccine. WHO Weekly Epidemiological Record $1981 ; 23: 177$.

(Accepted 18 fune 1982)

\title{
Are HLA antigens important in the development of alcohol-induced liver disease?
}

\author{
R FAIZALLAH, J C WOODROW， N K KRASNER, R J WALKER, A I MORRIS
}

\begin{abstract}
The prevalences of $10 \mathrm{HLA}-\mathrm{A}$ and $16 \mathrm{HLA}-\mathrm{B}$ antigens were determined in 50 patients with alcoholic cirrhosis and 120 alcoholic patients without cirrhosis and compared with those in a control group of 550 healthy subjects from the same geographical area. B40 was absent in the patients with cirrhosis but was found in $18(15 \%)$ of the patients without cirrhosis $(p=0.0087)$. No other association was noted.

It is concluded that there is no good evidence to date of an association between HLA antigen state and susceptibility to alcohol-induced cirrhosis.
\end{abstract}

\section{Introduction}

While the quantity of alcohol consumed and duration of consumption probably play a major part in the pathogenesis of alcohol-induced cirrhosis, other as yet poorly identified factors exist since most alcoholics do not develop cirrhosis despite very heavy drinking. ${ }^{1}$ One possible factor-genetic predispositionhas been studied in some detail by investigation of the HLA polymorphism among alcoholics. The results have so far been conflicting, some workers showing no evidence of any association between a particular HLA antigen and alcohol-induced cirrhosis ${ }^{2}$ while others have shown possible linkage with A28, B8, B13, and $B 40,{ }^{3-5}$ all in fairly small groups. In the present study we investigated a larger number of patients to assess their antigen state and determine whether there was any association with alcohol-induced cirrhosis.

Gastrointestinal Unit, Walton Hospital, Liverpool L9 1AE

R FAIZALLAH, MB, MRCP, medical registrar

N K KRASNER, MD, FRCP, consultant physician and gastroenterologist

R J WALKER, BSC, FRCP, consultant physician

A I MORRIS, MD, MRCP, consultant physician and senior lecturer

Department of Medicine, University of Liverpool, Liverpool L69 3BX J C WOODROW, MD, FRCP, professor

\section{Subjects and method}

Over two years we studied 170 consecutive alcoholics, all of whom had been admitted for detoxification or treatment of alcoholism. Fifty patients showed signs of chronic liver disease, and histology of liver biopsy specimens in 39 showed cirrhosis; in the remaining 11 liver biopsy was contraindicated and cirrhosis was diagnosed on clinical and biochemical grounds-for example, evidence of portal hypertension or hepatic encephalopathy. The group with cirrhosis comprised 15 women (mean age 58.1 \pm SD 10.5 years) and 35 men (mean age 54.9 \pm 9.4 years). The mean alcohol intake in this group was $194+96 \mathrm{~g} /$ day for a mean duration of $15 \cdot 3+8 \cdot 3$ years. Of the remaining 120 patients, 26 had no biochemical evidence of liver injury or any clinical evidence of liver disease; liver biopsy was unjustified in these and they were included in the group without cirrhosis. In the remaining 94 there was biochemical evidence of liver injury and liver biopsy yielded either normal findings or evidence of liver injury short of cirrhosis, the commonest being steatosis. Of these patients, 51 were women (mean age 48.1 $\pm 12 \cdot 8$ years) and 69 men (mean age $48.4 \pm 12.9$ years.) The mean alcohol intake in this group without cirrhosis was $186 \cdot 8 \pm 115 \mathrm{~g}$ pure alcohol daily for a mean of $8 \cdot 5 \pm 7 \cdot 4$ years. Lymphocytes from venous blood samples were typed by a modified cytotoxicity technique ${ }^{6}$ for specificity to 10 HLA-A and 16 HLA-B antigens. $\mathrm{ABO}$ blood groups were determined on the blood samples and compared with those of a large control series from the same geographical area.

Serum samples were tested for the presence of antinuclear, smoothmuscle, mitochondrial, parietal cell, and reticulin antibody by fluorescence antibody methods. Tests for the presence of hepatitis B surface antigen ( $\mathrm{HBsAg})$ and hepatitis $\mathrm{B}$ core antigen $(\mathrm{HBcAg})$ were carried out in most cases. Relative risks were calculated according to the method of Haldane.?

\section{Results}

Table I gives the prevalences of the HLA-A and B series antigens in alcoholic patients with and without cirrhosis and the controls together with the significances of the differences between the three groups. B40 was absent in the patients with cirrhosis but present in $18(15 \%)$ of those without cirrhosis and in $64(11.6 \%)$ of the normal controls. No other noticeable differences were apparent, in particular with regard to $\mathrm{A} 28, \mathrm{~B} 8$, and $\mathrm{B} 13$.

Table II gives the prevalences of the $\mathrm{ABO}$ blood groups in patients and controls; there was no significant difference between the three groups. Four patients showed very low titres of antinuclear antibodies; two had antibodies to smooth-muscle, one to reticulin, and six to 